\title{
Expression and activity of Apaf1 and caspase-9 in granulosa cells during follicular atresia in pig ovaries
}

\author{
T. Matsui, N. Manabe*, Y. Goto, N. Inoue, S. Nishihara and H. Miyamoto \\ Unit of Anatomy and Cell Biology, Department of Animal Sciences, Kyoto University, \\ Kyoto 606-8502, Japan
}

\begin{abstract}
Apoptosis in granulosa cells plays a crucial role in ovarian follicular atresia, but the intracellular regulating mechanism, especially the mitochondrion-dependent apoptosis signalling pathway, is still largely unknown. This study examined whether the mitochondrial pathway is associated with granulosa cell apoptosis during atresia in pig ovaries. Both mRNAs of caspase-9 and apoptotic protease-activating factor 1 (Apaf1), which are major signal transducing components in the mitochondrial pathway, were detected in granulosa cells in healthy, early atretic and progressed atretic follicles by RT-PCR. No changes in the expression of Apaf1 mRNA were seen during follicular atresia, but the expression of caspase-9 mRNA increased during atresia. Apaf1 protein was steadily detected in
\end{abstract}

granulosa cells prepared from healthy, early atretic and progressed atretic follicles by western blot analysis, but high expression of the precursor of caspase-9 (procaspase9) was detected only in granulosa cells of healthy follicles. Decreased procaspase-9 protein was demonstrated during follicular atresia. Proteolytic activity of caspase-9 increased during atresia, in agreement with the diminution of procaspase-9 protein. Intensive expression of caspase9 mRNA was demonstrated in the granulosa cells of early atretic and progressed atretic follicles but not in those of healthy follicles. These results indicate that the mitochondrial signalling pathway, which is mediated by Apaf1 and caspase-9, plays a crucial role in determining the fate of granulosa cells during atresia in pig ovaries.

\section{Introduction}

In mammalian ovaries, more than $99 \%$ of the follicles undergo atresia at various stages of follicle development (Tilly, 1996, 1998; Kaipia and Hsueh, 1997). Manabe et al. $(1996 a, 1997,1998)$ indicate that the degeneration of atretic follicles in mammalian ovaries can be explained, at least in part, by apoptotic cell death of granulosa cells. In the early stage of atresia in pig ovaries, apoptosis demonstrated histochemically and ultrastructually was seen in scattered granulosa cells located on the inner surface of the follicular wall, but not in cumulus cells, oocytes or the cells of internal or external theca layers (Manabe et al., 1996a; Sugimoto et al., 1998). However, the apoptotic signal transducing pathway system that mediates apoptosis in granulosa cells of pig ovaries is not known.

The process of apoptosis is triggered by diverse signals (Tilly, 1996) and various stimuli of apoptosis lead to the activation of intracellular caspase cascades, in which at least 14 caspases have been identified to date (Grutter, 2000). Some of the caspase cascades mediate apoptotic cell death in mammalian ovaries (Khan et al.,

*Correspondence

Email: manabe@kais.kyoto-u.ac.jp
2000; Johnson and Bridgham, 2002). There are two major apoptosis signalling pathways: cell-death receptordependent and mitochondrion-dependent (Nagata, 1997; Ashkenazi and Dixit, 1998; Green and Reed, 1998). The receptor-dependent pathway is triggered by members of the death receptor superfamily, Fas/APO$1 /$ CD95, tumour necrosis factor (TNF) receptor- 1 and -2 , and TNF-related apoptosis-inducing ligand (TRAIL) receptor-4 and -5 . In the mitochondrion-dependent pathway, various cellular stresses induce cytochrome $c$ release from the mitochondria; and cytochrome $c$ binds to apoptotic protease-activating factor 1 (Apaf1) (Zou et al., 1997; Robles et al., 1999), which in turn selfassociates and binds with procaspase-9, a zymogen of caspase-9. Procaspase-9 protein, although limited, has proteolytic activity without being cleaved (Stennicke et al., 1999). Generally, the complex molecule (cytochrome C-Apaf1-procaspase-9), called apoptosome, cleaves procaspase- 9 protein and makes it active, and then the cleaved or activated caspase- 9 activates downstream caspases, such as caspase-3 (Grutter, 2000; Wang, 2001). In granulosa cells of healthy follicles, the inactive form of caspase-3 (procaspase-3) was demonstrated, but procaspase-3 protein was cleaved and activated in granulosa cells prepared from atretic follicles (Izawa et al., 1998; Manabe et al., 1998). It is not yet 
understood which apoptosis signalling pathway plays a critical role in determining granulosa cell apoptosis during atresia in pig ovaries.

In the present study, attempts were made to determine the role of the mitochondrion-dependent signalling pathway in granulosa cell apoptosis under physiological conditions. The changes in expression of Apaf1 and procaspase- 9 proteins, and Apaf1 and caspase- 9 mRNAs were examined by western blot analysis and RT-PCR, respectively, and the changes in the activity of caspase- 9 were assessed biochemically. In addition, the changes in the localization of caspase- 9 mRNA were investigated by in situ hybridization.

\section{Materials and Methods}

\section{Preparation of granulosa cells}

The ovaries were obtained from mature sows of $>120 \mathrm{~kg}$ body weight from a local abattoir. Individual antral follicles, approximately $3 \mathrm{~mm}$ in diameter, were dissected from the ovaries under a surgical dissecting microscope (SZ40, Olympus, Tokyo). Each follicle was classified as morphologically healthy or atretic and further subdivided into early and progressed atretic follicles (approximately 15 follicles per ovary were used). Follicular fluid from each follicle was collected using a $1 \mathrm{ml}$ syringe, separated by centrifugation at $3000 \mathrm{~g}$ for $10 \mathrm{~min}$ at $4{ }^{\circ} \mathrm{C}$, and frozen and stored at $-80^{\circ} \mathrm{C}$. After biochemical analyses were performed, oestradiol and progesterone concentrations were measured retrospectively using [ $\left.{ }^{125} \mathrm{I}\right]$-radioimmunoassay kits (BioMérieux, Marcy-l'Etolle) to confirm the classification of the follicles. Follicles with a progesterone:oestradiol ratio of less than 15 were classified as healthy (Guthrie et al., 1995; Manabe et al., 1996b, 1998; Kimura et al., 1999). Each follicle was opened using fine watchmaker forceps and granulosa layers and cumulus-oocyte complexes were removed. The granulosa cells were isolated with Pasteur pipettes, collected, washed three times in PBS $(\mathrm{pH} \mathrm{7.2)}$ by centrifugation at $600 \mathrm{~g}$ for $5 \mathrm{~min}$ at room temperature (air-conditioned, $22-25^{\circ} \mathrm{C}$ ), and used for RT-PCR and western blot analyses.

\section{$R T-P C R$ analysis and $C D N A$ sequencing}

As described previously (Kimura et al., 1999; Wada et al., 2002; Nakayama et al., 2003), for RT-PCR analysis total RNA was extracted from granulosa-cell samples using a RNeasy mini kit (Qiagen, Chatsworth, $\mathrm{CA})$, treated with a RNase-free DNase kit (Qiagen), and then reverse-transcribed using a T-primed firststrand kit (Amersham Pharmacia Biotech, Piscataway, $\mathrm{NJ}$ ) to synthesize cDNA. Primers for the amplification of partial cDNA sequences of Apaf1, caspase-9 and glyceraldehyde-3-phosphate dehydrogenase (GAPDH; GenBank Accession No. AF017079, used as an intrinsic control) were as follows: caspase-9 forward: $5^{\prime}$-GGCTG TCTAC GGCAC AGATG GA-3', reverse: 5'-CTGGC TCGGG GTTAC TGCCA G-3'; Apaf1 forward: 5'GATCG GAATG GAAAG TCGTT TCG-3', reverse: 5'CATTC CATTA TCGAC CTCCT GCTTG GC-3'; and GAPDH forward: 5'-TCTGC CGGCA GCCGC GTCCC TG-3', reverse: 5'-CACGC CACAG TTTCC CAGAG-3'. Expected PCR product sizes of Apaf1, caspase-9 and GAPDH were 498, 200 and 615 bp, respectively. PCR amplification was performed as follows: platinum Taq DNA polymerase (10 $000 \mathrm{U}$; Gibco BRL, Grand Island, NY) was added to cDNA mixture and denatured. The mixture was subjected to PCR in a thermal cycler (GeneAmp PCR Systems 2400; PE Applied Biosystems, Foster City, CA). The hot-start PCR cycles for Apaf1 and caspase- 9 were as follows: $96^{\circ} \mathrm{C}$ for $1 \mathrm{~min}$ and then 30 cycles of $94^{\circ} \mathrm{C}$ for $1 \mathrm{~min}, 58^{\circ} \mathrm{C}$ for $1 \mathrm{~min}, 72^{\circ} \mathrm{C}$ for $1 \mathrm{~min}$ and final extension period at $72^{\circ} \mathrm{C}$ for $10 \mathrm{~min}$. Hot-start PCR cycles for GAPDH were: $94^{\circ} \mathrm{C}$ for $3 \mathrm{~min}$ and then 25 cycles of $94^{\circ} \mathrm{C}$ for $1 \mathrm{~min}, 58^{\circ} \mathrm{C}$ for $1 \mathrm{~min}, 72^{\circ} \mathrm{C}$ for $1 \mathrm{~min}$ and then one cycle at $72^{\circ} \mathrm{C}$ for $10 \mathrm{~min}$. Electrophoresis of PCR products was carried out using $2 \%(\mathrm{w} / \mathrm{v})$ agarose gels (Sigma Aldrich Chemicals, St Louis, MO) and ethidium bromide (Wako Pure Chemicals, Osaka) was used for staining. A ready-load 100 bp DNA ladder (Gibco) was used as a molecular weight marker for electrophoresis. The stained gels were recorded after electrophoresis with a digital fluorescence-recorder (LAS-1000; Fuji Film, Tokyo) and each mRNA expression level, the fluorescence intensity of each band of PCR product, was quantified using ImageGauge (Fuji Film) on a Macintosh computer. The relative abundance of specific mRNA was normalized to the relative abundance of GAPDH mRNA. The DNA sequence of each PCR product was determined using an automatic DNA sequencer (ABI Prism 310; PE Applied Biosystems), according to the manufacturer's protocol, to confirm the expression of Apaf1 and caspase9 mRNAs.

\section{Western blot analysis}

As previously reported (Nishihara et al., 2000; Nakayama et al., 2003), for western blot analysis the protein fraction (50 $\mu \mathrm{g}$ per lane) prepared from each sample was separated by $10-20 \%$ gradient SDSPAGE (Wako) and then transferred on to nitrocellulose membranes (Hybond-C, Amersham Pharmacia). The membranes were stained with $0.2 \%(\mathrm{w} / \mathrm{v})$ Ponceau S solution (Serva Electrophoresis, Heidelberg) and then immersed in blocking solution $(0.1 \mathrm{~mol}$ Tris- $\mathrm{HCl} \mathrm{I-1}$, $\mathrm{pH} 7.6,5 \%(\mathrm{w} / \mathrm{v})$ skimmed milk, $0.05 \mathrm{~mol} \mathrm{NaCl} \mathrm{I^{-1 }}$, $0.1 \%(\mathrm{v} / \mathrm{v})$ Tween 20; Sigma) for $30 \mathrm{~min}$, and incubated with rabbit polyclonal anti-Apaf1 antibody $(1: 2000$ dilution with blocking solution; Chemicon International, Temecula, CA) or rabbit polyclonal anti-procaspase-9 (1:2000 dilution with blocking solution; Pharmingen, San Diego, CA) for $18 \mathrm{~h}$ at $4^{\circ} \mathrm{C}$. After washing, the membranes 
were incubated with horseradish peroxidase-conjugated goat anti-rabbit IgG antibody (Jackson Immuno-Research Laboratories, West Grove, PA) for $1 \mathrm{~h}$ at $25^{\circ} \mathrm{C}$ and then chemiluminescence was visualized using an ECL system (Amersham Pharmacia) according to the manufacturer's protocol. The chemiluminescence was recorded with a digital fluorescence recorder, and then each protein expression level, the chemiluminescence intensity of each protein band, was quantified using ImageGauge on a Macintosh computer.

\section{Enzyme activity assay}

The proteolytic activity of caspase- 9 was determined using the caspase-9 colorimetric protease assay kit (MCH-6; Chemicon) according to the manufacture's protocol. Briefly, fresh granulosa cells prepared from healthy, early atretic and progressed atretic follicles were washed in PBS and then lysed in lysis solution (50 mmol Tris- $\mathrm{HCl} \mathrm{I}^{-1}, \mathrm{pH}^{2} .4,150 \mathrm{mmol} \mathrm{NaCl} \mathrm{I}^{-1}$, $20 \mathrm{mmol}$ EDTA $\mathrm{I}^{-1}, 50 \mathrm{mmol}^{\mathrm{NaF} \mathrm{I}}{ }^{-1}, 0.5 \%(\mathrm{v} / \mathrm{v})$ Nonidet P-40, $0.1 \mathrm{mmol} \mathrm{Na}_{3} \mathrm{VO}_{4}$ I-1 $^{-1}, 20 \mathrm{mg}$ leupeptin $\mathrm{ml}^{-1}, 20 \mathrm{mg}$ aprotinin $\mathrm{ml}^{-1}, 1 \mathrm{mmol}$ dithiothreitol $\mathrm{I}^{-1}$ and $1 \mathrm{mmol}$ phenylmethylsulphonyl fluoride $\mathrm{I}^{-1}$ ). After centrifugation at $10000 \mathrm{~g}$ for $5 \mathrm{~min}$, each supernatant was collected and protein concentration in the supernatant was measured by the Bradford assay kit (Bio-Rad Laboratories, Melville, NY). The supernatant was incubated with LEHD-p-nitroaniline (LEHD-pNA; a colorimetric peptidyl substrate for caspase-9) for $2 \mathrm{~h}$ at $37^{\circ} \mathrm{C}$. Free $p N A$ was measured using a microplate reader (Model 450; Bio-Rad) at a wavelength of $405 \mathrm{~nm}$ to assess the proteolytic activity of caspase- 9 .

\section{Apoptotic cell detection and in situ hybridization}

Apoptotic cells in pig ovarian sections were detected immunohistochemically according to the method described by Watanabe et al. (1999). Briefly, frozen serial sections $5 \mu \mathrm{m}$ thick, mounted on glass slides precoated with 3-aminopropyltriethoxysilane (Sigma) were fixed with $10 \%$ phosphate buffered formalin. After washing with PBS, the sections were treated with $0.3 \%(\mathrm{v} / \mathrm{v})$ $\mathrm{H}_{2} \mathrm{O}_{2}$ methanol for $30 \mathrm{~min}$ and washed with PBS containing $0.02 \%(\mathrm{v} / \mathrm{v})$ Tween 20 (PBST; Sigma). The sections were then incubated with polyclonal rabbit antisingle strand DNA (ssDNA) antibody (1:100 diluted with PBS; Dako, Glostrup) for $18 \mathrm{~h}$ at $4^{\circ} \mathrm{C}$, washed with PBST and incubated with Envision solution for rabbit antibody (Dako) for 60 min. After washing with PBST, the sections were reacted with $0.05 \%(\mathrm{w} / \mathrm{v}) 3,3^{\prime}$-diaminobenzidine (Wako) and $0.002 \%(\mathrm{v} / \mathrm{v}) \mathrm{H}_{2} \mathrm{O}_{2}$ in $50 \mathrm{mmol}$ Tris- $\mathrm{HCl}$ $\mathrm{I}^{-1}, \mathrm{pH} 7.2$, for $1 \mathrm{~min}$ at $25^{\circ} \mathrm{C}$, washed with distilled water, counterstained with haematoxylin, mounted with Entellan (Merck, Darmstadt) and examined using light microscopy.
The localization of caspase- 9 mRNA by in situ hybridization was visualized by synthesizing digoxigenin (DIG)-labelled antisense and sense cRNA probes for caspase-9 mRNA using a Lig'n Scribe kit (Ambion, Austin, TX) and DIG-RNA-labelling kit (Roche Diagnostics, Rotkreuz) according to the manufacturer's protocols. Frozen ovarian sections were fixed with $4 \%(\mathrm{v} / \mathrm{v})$ paraformaldehyde (PFA; Wako) in PBS for 8 min, washed with PBS and treated with $0.2 \mathrm{~mol} \mathrm{HCl} \mathrm{I}^{-1}$ for $10 \mathrm{~min}$ at room temperature (air-conditioned, $22-25^{\circ} \mathrm{C}$ ). After washing with PBS, the sections were digested with proteinase $\mathrm{K}$ ( $1 \mu \mathrm{g} \mathrm{ml}{ }^{-1}$; Sigma) in PBS at $37^{\circ} \mathrm{C}$ for $10 \mathrm{~min}$, post-fixed with $4 \%$ PFA in PBS, immersed with $2 \mathrm{mg} g l y c i n e ~ \mathrm{ml}^{-1}$ in PBS for 3 min, and washed thoroughly with PBS. The sections were prehybridized with $10 \mathrm{mmol}$ Tris- $\mathrm{HCl} \mathrm{I}^{-1}$, pH 7.4, containing 600 mmol NaCl I-1, $1 \times$ Denhardt's solution, $50 \%(\mathrm{v} / \mathrm{v})$ deionized formamide for $1 \mathrm{~h}$ at $25^{\circ} \mathrm{C}$, and hybridized with an antisense-DIG-caspase-9 cRNA probe for $18 \mathrm{~h}$ at $45^{\circ} \mathrm{C}$. Each probe $(1 \mu \mathrm{g} \mathrm{ml}-1)$ was diluted in $10 \mathrm{mmol}$ Tris- $\mathrm{HCl} \mathrm{I}{ }^{-1}, \mathrm{pH} \mathrm{7.4,1} \mathrm{mmol} \mathrm{EDTA}$ $\mathrm{I}^{-1}, 600 \mathrm{mmol} \mathrm{NaCl} \mathrm{I} \mathrm{I}^{-1}, 1 \times$ Denhardt's solution, $10 \mathrm{mg}$ yeast tRNA $\mathrm{ml}^{-1}, 10 \mathrm{mg}$ salmon testicular DNA $\mathrm{ml}^{-1}, 5 \%(\mathrm{v} / \mathrm{v})$ dextran sulphate and $50 \%(\mathrm{v} / \mathrm{v})$ deionized formamide. The sections were washed with $2 \times$ standard saline citrate (SSC) for 2 h, $0.5 \times$ SSC for $2 \mathrm{~h}$ and $0.2 \times$ SSC for $1 \mathrm{~h}$ at $45^{\circ} \mathrm{C}$, and then equilibrated with 100 mmol Tris-HCl I-1, $\mathrm{pH} 7.5$, containing $150 \mathrm{mmol}$ $\mathrm{NaCl} \mathrm{I}^{-1}$ (THS). Sections were then treated with blocking solution (Roche) for $1 \mathrm{~h}$ at room temperature, incubated with alkaline phosphatase (AP)-conjugated sheep antiDIG antibody (1:500 diluted with blocking solution; Roche) for $18 \mathrm{~h}$ at $4^{\circ} \mathrm{C}$, washed with $\mathrm{THS}$, and rinsed with $100 \mathrm{mmol}$ Tris- $\mathrm{HCl} \mathrm{I}^{-1}$, $\mathrm{pH} 9.5,100 \mathrm{mmol} \mathrm{NaCl} \mathrm{I}^{-1}$ and $100 \mathrm{mmol} \mathrm{MgCl}_{2} \quad \mathrm{I}^{-1}$ (THSM). They were immersed with THSM containing $0.4 \mathrm{mmol}$ nitroblue tetrazolium chloride $\mathrm{I}^{-1}$ (Sigma), $0.4 \mathrm{mmol}$ 5-bromo-4-chloro-3indolylphosphate4-toluidine salt $\mathrm{I}^{-1}$ (Sigma) and $1 \mathrm{mmol}$ levamisole $\mathrm{I}^{-1}$ (Sigma), and then incubated for $90 \mathrm{~min}$ at $25^{\circ} \mathrm{C}$. The sections were immersed with PBS, mounted with Histofine (Nichirei, Tokyo) and examined under a light microscope. Dimethyl pyrocarbonate (Sigma)treated water was used throughout the staining processes. As negative controls, serial sections were hybridized with a DIG-labelled sense cRNA probe or without any probes, or incubated without anti-DIG antibody. Any controls yielded completely negative results.

\section{Statistical analysis}

All experiments including follicle isolation and granulosa cell preparation were repeated three times with separate groups (nine sows per group) for independent observation. Homogeneity of variance was assessed using StatView 4.5 (Abacus Concepts, Berkely, CA) on a Macintosh computer before ANOVA processing. ANOVA with Fisher's least significant differences test for biochemical data and Wilcoxon's signed-rank tests 
(a)

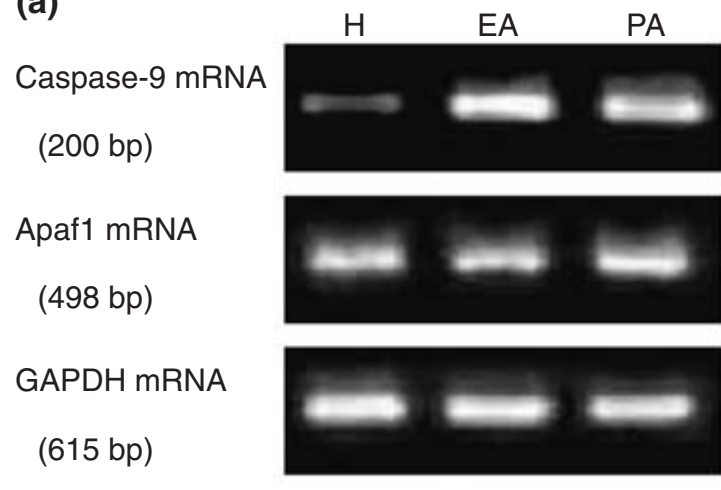

(c)

Procaspase-9

(47 kDa)

Apaf1

$(130 \mathrm{kDa})$
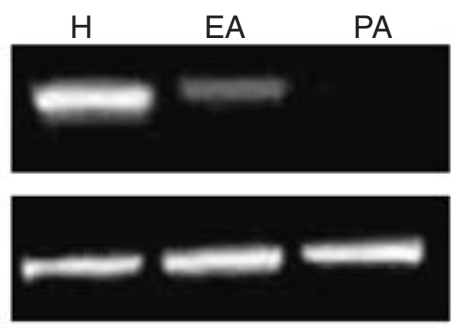

(b)

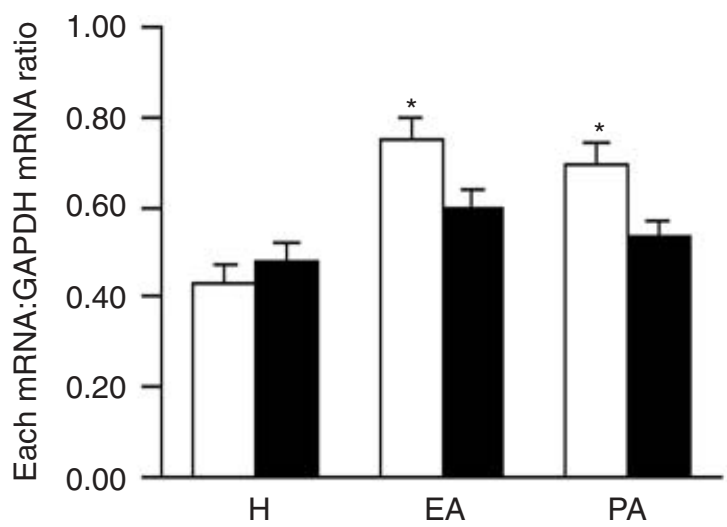

(d)

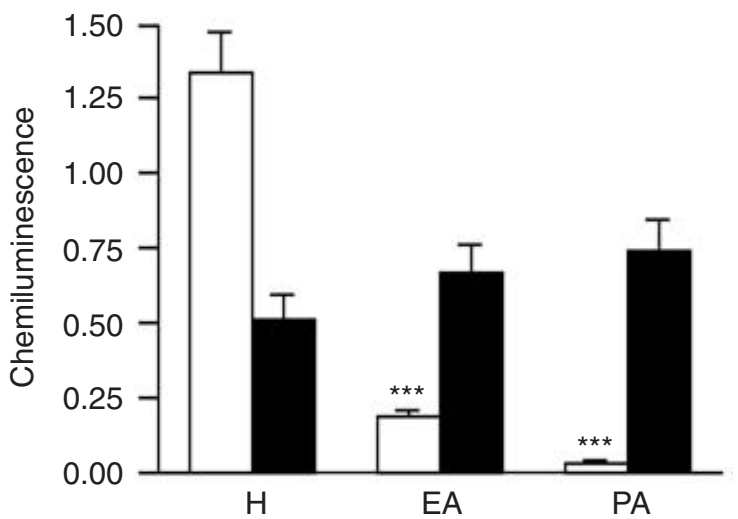

Fig. 1. RT-PCR products, expression and chemiluminescence western blot analysis for caspase-9, apoptotic proteaseactivating factor 1 (Apaf1) and glyceraldehyde-3-phosphate dehydrogenase (GAPDH). (a) RT-PCR products for caspase-9, Apaf1 and GAPDH mRNAs. (b) Caspase-9 ( $\square$ ) and Apaf1 (ם) mRNA expression (caspase-9 mRNA:GAPDH mRNAa and Apaf1 mRNA:GAPDH mRNA ratios, respectively) in granulosa cells of healthy $(H)$, early atretic $(E A)$ and progressed atretic (PA) pig follicles. (c) Chemiluminescence western blot analysis for procaspase-9 (the precursor of caspase-9) and Apaf1 proteins in granulosa cells from healthy, early atretic and progressed atretic pig follicles. (d) Procaspase-9 ( $\square$ ) and Apaf1 (ם) proteins in granulosa cells from healthy, early atretic and progressed atretic follicles were quantified by western blot image analysis and shown as chemiluminescence intensity. All data in (b) and (d) are shown as means \pm SEM. ${ }^{*} P<0.05$ and ${ }^{* * *} P<0.001$ versus each healthy sample.

for histological estimation were carried out using StatView 4.5. Differences at $P<0.05$ were considered significant.

\section{Results}

Expression of Apaf1 and caspase-9 mRNAs in granulosa cells

The RT-PCR products detected in the present study were confirmed to be pig Apaf1 and caspase- 9 by the cDNA sequence determination. The cDNA sequence of the corresponding domain of Apaf1 was 5'-GATCG GAATG GAAAG TCGTT TCGTT ATTAT TTACA TGATC TTCAA GTAGA TTTTC TTACA GAGAA GAATT GCAGC CAGCT TCAGG ATCTA CATAA GAAGA TAATC ACTCA GTTTC AGAGA TATCA CCAGC CGCAT ACTCT TTCAC CAGAT CAGGA AGACT GTATG TATTG CTACA
ACTTT CTGGC CTATC ACGTG GCCAG TGCCA AGATG CACAA GGAAC TTTGT GCTTT AATGT TTTCC CTGGA TTGGA TTAAA GCAAA AACAG AACTT GTAGG CCCTG CTCAT CTGAT TCATG AATTT GTGGA ATACA GACAT ATACT AGATG AAAAG GATTG TGCAG TCAGT GAGAA TTTTC AGGAG TTTTT ATCTT TAAAT GGACA CCTTC TTGGA CGACA GCCAT TTCCT AATAT TGTAC AACTG GGTCT CTGTG AGCCG GAAAC TTCAG AAGTT TATCA GCAAG CTAAG CTGCA GGCCA AGCAG GAGGT CGATA ATGGA ATG-3' (498 bp). The similarity between pig and human Apaf1 (GenBank Accession No. AJ243048) was $99.6 \%$. The cDNA sequence of the corresponding domain of caspase-9 was $5^{\prime}$-GGCTG TCTAC GGCAC AGATG GATGC CCTGT GTCGG TCGAG AAGAT TGTGA ACATC TTCAA TGGGA CCAGC TGCCC CAGCC TGGGA GGGAA GCCCA AGCTC TTTTT CATCC AGGCC TGTGG TGGGG AGCAG AAAGA CCATG GGTTT GAGGT GGCCT CCACT TCCCC 
TGAAG ACGAG TCCCC TGGCA GTAAC CCCGA GCCAG-3' (200 bp). The similarity between pig and human caspase-9 (GenBank Accession No. U56390) was $100 \%$.

Apaf1, caspase-9 and GAPDH mRNAs were detected in isolated granulosa cells of healthy, early atretic and progressed atretic follicles by RT-PCR (Fig. 1a). No significant difference in Apaf1 mRNA or GAPDH mRNA ratio was seen among granulosa cells of healthy, early atretic or progressed atretic follicles (Fig. 1b). Abundance of caspase-9 mRNA in granulosa cells of early atretic and progressed atretic follicles was higher than in those of healthy follicles (Fig.1a). Changes in the fluorescence intensity quantified using an automatic image analyser showed that caspase-9 mRNA expression increased during follicular atresia $(P<0.05$; Fig. $1 \mathrm{~b})$.

\section{Changes in expression of Apaf1 and procaspase-9 proteins in granulosa cells}

No significant differences in Apaf1 protein expression among healthy, early atretic and progressed atretic follicles were shown in all stages of follicles (Fig. 1c,d). Strong immunoreaction for procaspase- 9 protein (precursor protein of caspase-9) was demonstrated in the granulosa cells of healthy follicles. Decreased expression of procaspase- 9 protein was seen in granulosa cells from early atretic follicles, and no expression of procaspase- 9 protein was detected in those from progressed atretic follicles (Fig. 1c). Changes in the chemiluminescence intensity quantified using an automatic image analyser showed that procaspase-9 protein expression decreased and finally disappeared during follicular atresia $(P<$ 0.001; Fig. 1d).

\section{Changes in activity of caspase-9 in granulosa cells}

Higher proteolytic activities of caspase-9 in isolated granulosa cells of early atretic and progressed atretic follicles than in those of healthy follicles were determined $(P<0.001)$, indicating the activation of caspase-9 during follicular atresia (Fig. 2).

\section{Localization of apoptotic cells and caspase-9 mRNA in follicles}

No ssDNA-positive apoptotic cell was observed in granulosa cells, internal thecal cells or external thecal cells of healthy follicles (Fig. 3a). Similar to previous studies (Manabe et al., 1996a, 1998; Nakayama et al., 2000, 2003), apoptosis occurred in granulosa cells located on the inner surface of the follicular wall in the follicles at the early stage of atresia (Fig. 3d), and positive reaction was seen in most granulosa cells of progressed atretic follicles (Fig. 3g).

In healthy follicles, trace or weak reaction for caspase9 mRNA was seen in granulosa cells and negative

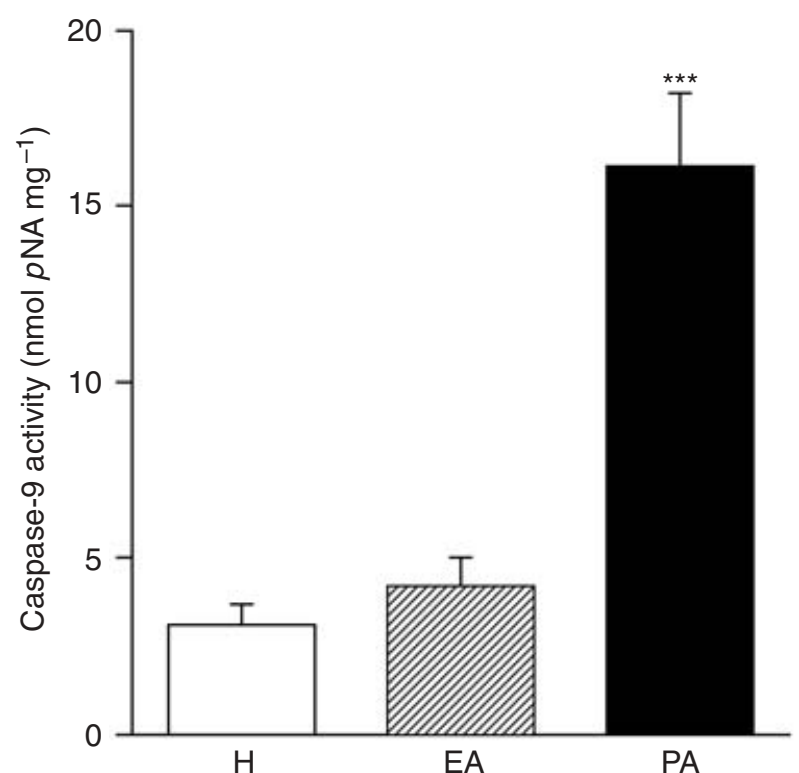

Fig. 2. Changes in activity of caspase-9 in granulosa cells from healthy $(\mathrm{H})$, early atretic $(\mathrm{EA})$ and progressed atretic $(\mathrm{PA})$ pig ovarian follicles. All data are shown as means \pm SEM. ${ }^{* * *} P<0.001$ versus healthy sample.

staining was observed in internal thecal cells or external thecal cells (Fig. 3b). Strong staining for caspase-9 mRNA was demonstrated in granulosa cells of both early atretic and progressed atretic follicles (Fig. 3e,h, respectively), indicating the increase in caspase- 9 mRNA expression in granulosa cells during follicular atresia. Negative staining for caspase-9 mRNA was seen in internal thecal cells or external thecal cells of early atretic follicles (Fig. 3e), and trace or weak reaction was observed in internal thecal cells of progressed atretic follicles (Fig. 3h). No positive reaction was seen in the sense-probe stainings used as negative controls (Fig. 3c,f,i).

\section{Discussion}

It has not been shown clearly which molecule(s) acts as an initial trigger for granulosa cell apoptosis during follicular atresia in mammalian ovaries (Tilly, 1996, 1998; Kaipia and Hsueh, 1997). Balance of survival and death factors is essential for the determination of growth, proliferation, differentiation and cell death in granulosa cells (Markstrom et al., 2002). Although the death receptor-dependent signalling pathway has been investigated thoroughly (Nagata, 1997; Ashkenazi and Dixit, 1998), there is insufficient information on the role of intracellular signalling molecules involving the mitochondrion-dependent signalling pathway in follicles of mammalian ovaries (Kaipia and Hsueh, 1997; Hsu and Hsueh, 2000). Until now, no report concerning the relationship between the Apaf1 and caspase-9 system 
(a)

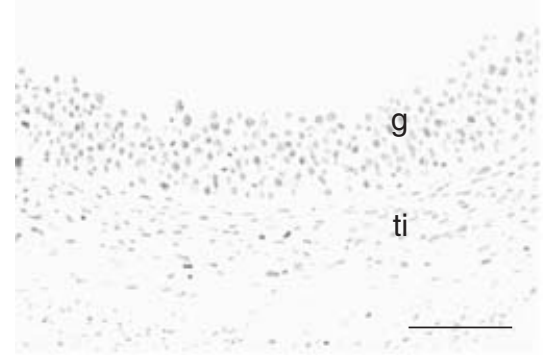

(d)
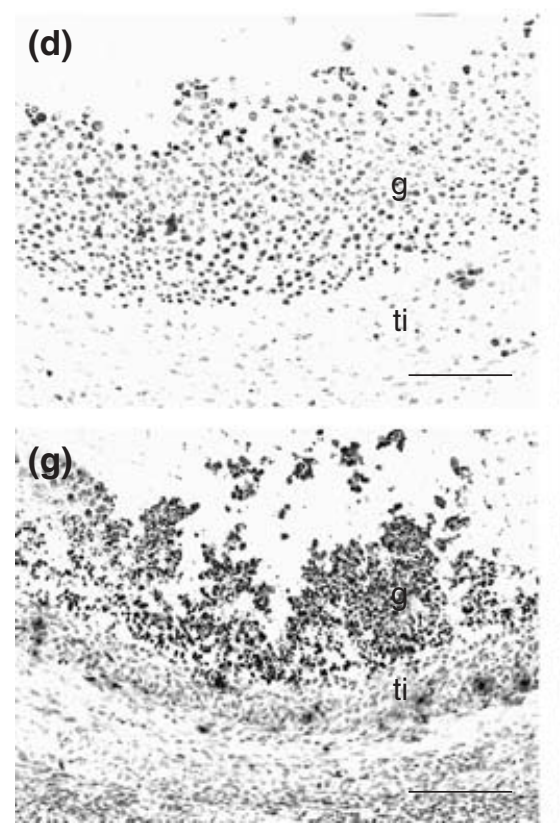

(b)
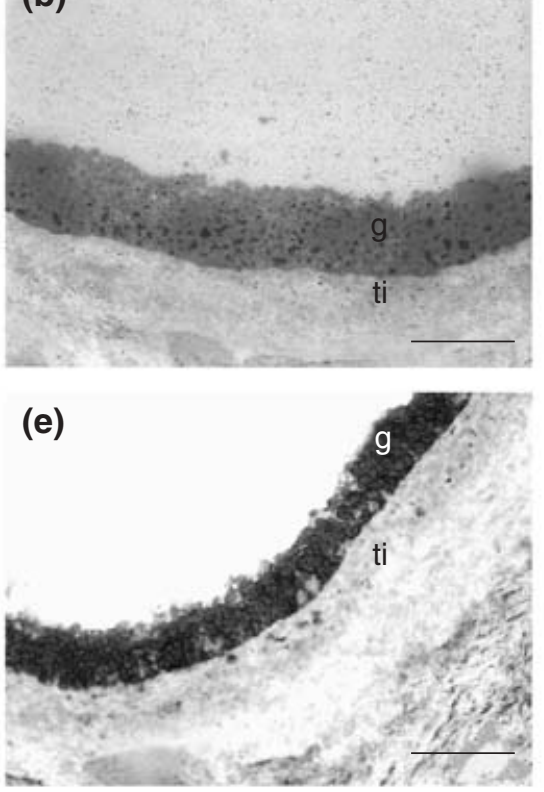

(h)

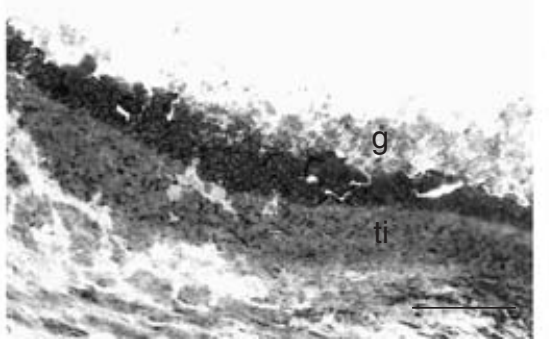

(c)

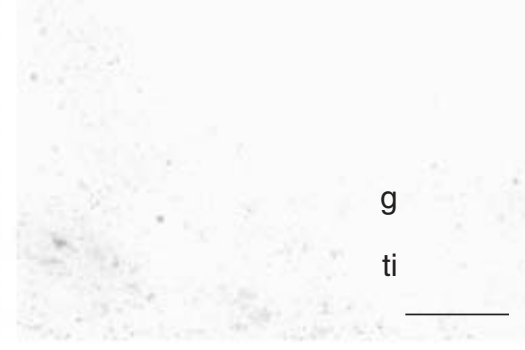

(f)

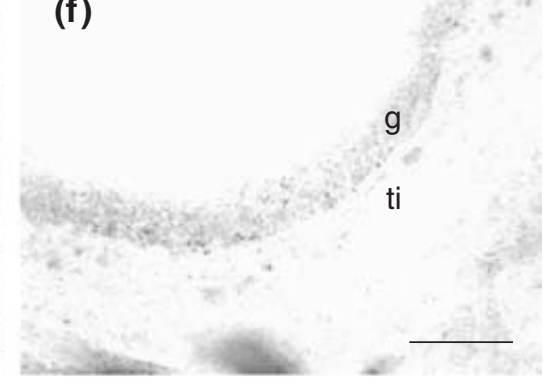

(i)

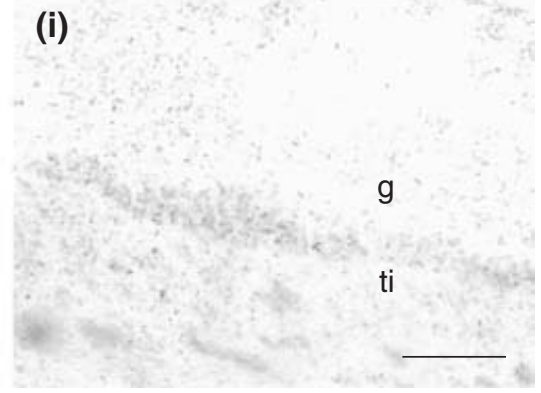

Fig. 3. Ovarian sections from ( $a, b$ and $c)$ healthy, $(d, e$ and $f)$ early atretic and (g,h and i) progressed atretic pig follicles. Apoptotic cells were demonstrated immunohistochemically using anti-single strand DNA (ssDNA) antibody ( $\mathrm{a}, \mathrm{d}$ and g). Representative sections were subjected to in situ hybridization with antisense cRNA probe for caspase-9 mRNA (b,e and h), and sense probe as negative control ( $c, f$ and i). No ssDNA positive cell was observed in healthy follicles (a). ssDNA positive apoptotic cells were seen in granulosa cells located on the inner surface of the follicular wall in the follicles at the early stage of atresia (d), and positive reaction was seen in most granulosa cells of progressed atretic follicles (g). Trace or weak reaction for caspase-9 mRNA was seen in granulosa cells of healthy follicles (b). Intense staining was seen in granulosa cells of both early atretic and progressed atretic follicles (e and h, respectively). No positive reaction was seen in sense-probe stainings (c, $\mathrm{f}$ and $\mathrm{i})$. g: granulosa cell layer; ti: theca interna layer. Scale bars represent $50 \mu \mathrm{m}$.

and granulosa cell apoptosis in a physiological situation has been published. The present study investigated whether the mitochondrion-dependent signalling pathway is involved in granulosa cell apoptosis during atresia in pig ovaries. In the mitochondrial signalling pathway, it is generally believed that when the cells receive a stressful stimulus which leads to mitochondrial damage, cytochrome $c$ is released from the mitochondria (Green and Reed, 1998; Wang, 2001) and binds with Apaf1 (Zou et al., 1997; Robles et al., 1999), and then the Apaf1-cytochrome $c$ complex binds with procaspase9 (Cecconi et al., 1998; Qin et al., 1999). The Apaf1cytochrome $c$-procaspase- 9 complex plays a key role in mitochondrion-dependent apoptosis (Cecconi, 1999; Grutter, 2000; Wang, 2001). The present study confirmed the constant expression of Apaf1 mRNA and Apaf1 protein in granulosa cells of healthy, early atretic and progressed atretic follicles, indicating that Apaf1 is expressed regardless of whether cells undergo apoptosis. However, proteolytic activity of caspase-9 in granulosa cells increased during follicular atresia, and inactive zymogen, procaspase-9 protein, decreased in granulosa cells. These data indicate that during follicular atresia, cytochrome $c$ released from the mitochondria binds with Apaf1 in granulosa cells, cytochrome $c$-Apaf1 complex binds with procaspase- 9 , which is cleaved and processed to its active form (caspase-9), and this leads to the processing and activation of procaspase- 3 , a downstream executor of apoptosis (Grutter, 2000). Thus, the authors consider that the mitochondrion-dependent signalling 
pathway is involved in granulosa cell apoptosis during follicular atresia in pig ovaries. The mitochondriondependent signalling pathway may not act as an initial trigger for granulosa cell apoptosis, but may contribute to amplification and propagation of apoptotic cell death in granulosa layers, and consequently rapidly remove atretic follicles.

The detailed mechanism underlying cytochrome $C$ release and its control by regulating factors, the $\mathrm{Bcl} 2$ family proteins, in ovarian tissues remains unclear (Vaux et al., 1988; Green and Reed, 1998; Cecconi, 1999; Hsu and Hsueh, 2000; Wang, 2001). In the mitochondrial signalling pathway, $\mathrm{Bcl} 2$ family proteins play bifacial roles, as apoptosis-inducing or apoptosisinhibiting factors (Cecconi, 1999). Diva/Boo, a novel anti-apoptotic $\mathrm{Bcl} 2$ family protein, is expressed restrictively in the ovary and epididymis of adult rodents and binds directly to Apaf1 (Inohara et al., 1998; Song et al., 1999). The binding of Diva/Boo with Apaf1 may induce conformation changes in the Apaf1 protein and thus inhibit the recruitment and processing of procaspase- 9 protein. Regulator molecules, like Diva/Boo, functioning on the upstream of mitochondrion-dependent signalling in granulosa cells of pig ovaries, need to be determined in the future.

Recently, perplexing findings on the mitochondriondependent signalling pathway have been reported in which cytochrome $c$ release from the mitochondria has been observed in cells undergoing apoptosis induced by a cell-death ligand-receptor (FasL-Fas and TNF $\alpha-T N F-$ receptor-1) (Hsu and Hsueh, 2000). For instance, Bid, which is a protein known to interact with $\mathrm{Bcl} 2$ protein and other Bcl 2 family proteins, acts as a specific proximal substrate of caspase-8 (a major caspase in the death receptor-dependent signalling pathway) in the cells with apoptosis induced by the FasL-Fas system (Thornberry and Lazebnik, 1998; Grutter, 2000). Activated caspase-8 truncates the full-length Bid protein, and then the truncated or activated Bid induces the release of cytochrome $c$ from the mitochondria to cytosol (Luo et al., 1998). Consequently, cytochrome c-Apaf1-caspase-9 complex-dependent apoptosis is induced. There have been no reports of whether there is such an intracellular cross-talk molecule in granulosa cells. In mammalian ovaries, the death-receptor-dependent signalling pathway, FasL-Fas (Sakamaki et al., 1997; Porter et al., 2001), TRAIL-TRAIL receptors (Wada et al., 2002), TNF $\alpha-T N F-$ receptor-2 (which acts as a survival factor in granulosa cells during follicular growth in pig ovaries) (Nakayama et al., 2003), and other cell-death ligand-receptor systems (Manabe et al., 1998, 2000) may contribute to the follicular selection process. As the present findings demonstrate that the mitochondrion-dependent signalling pathway is activated in granulosa cells of atretic follicles, future studies may identify the Bid-like intracellular cross-talk molecule(s) mediating between the death receptor-dependent signalling pathway and the mitochondrion-dependent signalling pathway in granulosa cells of pig ovaries.

The authors are grateful to T. Miyano and S. Katoh (Kobe University) for advice on the determination of healthy and atretic follicles and on preparation of granulosa cells. The authors also wish to thank M. Nakayama for excellent assistance. This work was supported by a Grant-in-Aid for Creative Scientific Research (13GS0008) to N. Manabe from the Ministry of Education, Science, Sports, Culture and Technology of Japan.

\section{References}

Ashkenazi A and Dixit VM (1998) Death receptors: signaling and modulation Science 281 1305-1308

Cecconi F (1999) Apaf1 and the apoptotic machinery Cell Death and Differentiation 6 1087-1098

Cecconi F, Alvarez-Bolado G, Meyer BI, Roth KA and Gruss P (1998) Apaf1 (CED-4 homolog) regulates programmed cell death in mammalian development Cell 94 727-737

Green DR and Reed JC (1998) Mitochondria and apoptosis Science 281 1309-1312

Grutter MG (2000) Caspases: key players in programmed cell death Current Opinion in Structural Biology 10 649-655

Guthrie HD, Cooper BS, Welch GR, Zakaria AD and Johnson LA (1995) Atresia in follicles grown after ovulation in the pig: measurement of increased apoptosis in granulosa cells and reduced follicular fluid estradiol-17ß Biology of Reproduction 52 920-927

Hsu SY and Hsueh AJW (2000) Tissue-specific Bcl-2 protein partners in apoptosis: an ovarian paradigm Physiological Reviews 80 593-614

Kaipia A and Hsueh AJW (1997) Regulation of ovarian follicle atresia Annual Review of Physiology 59 349-363

Inohara N, Gourley TS, Carrio R, Muniz M, Merino J, Garcia I, Koseki T, Hu Y, Chen S and Nunez G (1998) Diva, a Bcl-2 homologue that binds directly to Apaf-1 and induces $\mathrm{BH} 3$-independent cell death Journal of Biological Chemistry 27332 479-32 486

Izawa M, Nguyen PH, Kim HH and Yeh J (1998) Expression of the apoptosisrelated genes, caspase-1, caspase-3, DNA fragmentation factor, and apoptotic protease activating factor- 1 , in human granulosa cells Fertility and Sterility 70 549-552

Johnson AL and Bridgham JT (2002) Caspase-mediated apoptosis in the vertebrate ovary Reproduction 124 19-27

Khan SM, Dauffenbach LM and Yeh J (2000) Mitochondria and caspases in induced apoptosis in human luteinized granulosa cells Biochemical and Biophysical Research Communications $269542-545$

Kimura Y, Manabe N, Nishihara S, Matsushita H, Tajima C, Wada S and Miyamoto $\mathbf{H}$ (1999) Up-regulation of the $\alpha 2,6$-sialyltransferase messenger ribonucleic acid increases glycoconjugates containing $\alpha 2,6$ linked sialic acid residues in granulosa cells during follicular atresia of porcine ovaries Biology of Reproduction 60 1475-1482

Luo X, Budihardjo I, Zou H, Slaughter C and Wang X (1998) Bid, a Bcl2 interacting protein, mediates cytochrome $\mathrm{C}$ release from mitochondria in response to activation of cell surface death receptors Cell 94 481-490

Manabe N, Imai Y, Ohno H, Takahagi Y, Sugimoto and Miyamoto H (1996a) Apoptosis occurs in granulosa cells but not cumulus cells in the atretic antral follicles in the pig ovaries Experientia 52 647-651

Manabe N, Imai Y, Kimura $Y$, Myoumoto A, Sugimoto $M$, Miyamoto $H$, Okamura $\mathbf{Y}$ and Fukumoto $\mathbf{M}$ (1996b) $\mathrm{Ca}^{2+} / \mathrm{Mg}^{2+}$-dependent endonuclease but not $\mathrm{Ca}^{2+}$-dependent, $\mathrm{Mg}^{2+}$-dependent or cation-independent endonuclease is involved in granulosa cell apoptosis of pig atretic follicles Journal of Reproduction and Development 42 247-253

Manabe N, Imai Y, Myoumoto A, Kimura Y, Sugimoto M, Okamura Y, Fukumoto M, Sakamaki K and Miyamoto H (1997) Apoptosis occurs in granulosa cells but not cumulus cells in the atretic Graffian follicles in multiparous pig ovaries Acta Histochemica et Cytochemica $\mathbf{3 0}$ 85-92 
Manabe N, Kimura Y, Myoumoto A, Matsushita H, Tajima C, Sugimoto M and Miyamoto H (1998) Role of granulosa cell apoptosis in ovarian follicle atresia. In Apoptosis: Its Roles and Mechanism pp 97-111 Eds T Yamada and Y Hashimoto. Academic Societies Press, Tokyo

Manabe N, Myoumoto A, Tajima C, Fukumoto M, Nakayama M, Uchio K, Yamaguchi $\mathbf{M}$ and Miyamoto $\mathbf{H}$ (2000) Immunochemical characteristics of a novel cell death receptor and a decoy receptor on granulosa cells of porcine ovarian follicles Cytotechnology 33 189-201

Markstrom E, Svensson EC, Shao R, Svanberg B and Billing H (2002) Survival factors regulating ovarian apoptosis: dependence on follicle differentiation Reproduction 123 23-30

Nagata S (1997) Apoptosis by death factor Cell 88 355-365

Nakayama M, Manabe N, Nishihara S and Miyamoto H (2000) Speciesspecific differences in apoptotic cell localization in granulosa and theca interna cells during follicular atresia in porcine and bovine ovaries Journal of Reproduction and Development 46 147-156

Nakayama M, Manabe N, Inoue N, Matsui T and Miyamoto H (2003) Changes in the expression of tumor necrosis factor (TNF) $\alpha$, TNF $\alpha$ receptor (TNFR) 2 and TNFR-associated factor 2 in granulosa cells during atresia in pig ovaries Biology of Reproduction 68 530-535

Nishihara S, Manabe N, Nakayama M, Wada S, Inoue N and Miyamoto H (2000) Changes in cell adhesion molecules during follicular atresia in porcine ovaries Journal of Reproduction and Development $\mathbf{4 6}$ 325-334

Porter DA, Harman RM, Cowan RG and Quirk SM (2001) Relationship of Fas ligand expression and atresia during bovine follicle development Reproduction 121 561-566

Qin H, Srinivasula SM, Wu G, Fernandes-Alnemri T, Alnemri ES and Shi Y (1999) Structural basis of procaspase-9 recruitment by the apoptotic protease-activating factor 1 Nature 399 549-557

Robles R, Tao XJ, Trbovich AM, Maravel DV, Nahum R, Perez GI, Tilly KI and Tilly JL (1999) Localization, regulation and possible consequences of apoptotic protease-activating factor-1 (Apaf-1) expression in granulosa cells of the mouse ovary Endocrinology 140 2641-2644

Sakamaki K, Yoshida H, Nishimura Y, Nishikawa S, Manabe N and Yonehara S (1997) Involvement of Fas antigen in ovarian follicular atresia and leuteolysis Molecular Reproduction and Development 47 11-18

Song Q, Kuang Y, Dixit VM and Vincenz C (1999) Boo, a novel negative regulator of cell death, interacts with Apaf-1 EMBO Journal 18 167-178
Stennicke HR, Deveraux QL, Humke EW, Reed JC, Dixit VM and Salvesen GS (1999) Caspase-9 can be activated without proteolytic processing Journal of Biological Chemistry 274 8359-8362

Sugimoto M, Manabe N, Kimura Y, Myomoto A, Imai Y, Ohno H and Miyamoto $\mathbf{H}$ (1998) Ultrastructural changes in granulosa cells in porcine antral follicles undergoing atresia indicate apoptotic cell death Journal of Reproduction and Development 44 7-14

Thornberry NA and Lazebnik Y (1998) Caspases: enemies within Science 281 1312-1316

Tilly JL (1996) Apoptosis and ovarian function Reviews of Reproduction 1 $162-172$

Tilly JL (1998) Cell death and species propagation: molecular and genetic aspects of apoptosis in the vertebrate female gonad. In When Cells Die pp 431-452 Eds RA Locksjin, Z Zakeri and JL Tilly. Wiley-Liss, New York

Vaux DL, Cory S and Adams JM (1988) Bcl-2 gene promotes haemopoietic cell survival and cooperates with c-myc to immortalize pre-B cells Nature 335 440-442

Wada S, Manabe N, Inoue N, Nakayama M, Matsui T and Miyamoto $\mathbf{H}$ (2002) TRAIL-decoy receptor-1 disappears in granulosa cells of atretic follicles in porcine ovaries Journal of Reproduction and Development 48 167-173

Wang X (2001) The expanding role of mitochondria in apoptosis Genes and Development 15 2922-2933

Watanabe I, Toyoda M, Okuda J, Tenjo T, Tanaka K, Yamamoto T, Kawasaki H, Sugiyama T, Kawarada Y and Tanigawa N (1999) Detection of apoptotic cells in human colorectal cancer by two different in situ methods: antibody against single stranded DNA and terminal deoxynucleotidyl transferase mediated dUTP-biotin nick end-labeling (TUNEL) methods Japanese Journal of Cancer Research 90 188-193

Zou H, Henzel WJ, Liu X, Lutschg A and Wang X (1997) Apaf-1, a human protein homologous to $C$. elegans CED-4, participates in cytochrome C-dependent activation of caspase-3 Cell 90 405-413

Received 29 November 2002.

First decision 18 February 2003.

Revised manuscript received 12 March 2003.

Accepted 9 April 2003. 